\title{
PENGARUH LINGKUNGAN KERJA DAN MOTIVASI BERPRESTASI TERHADAP KINERJA GURU MADRASAH IBTIDAIYAH DI KECAMATAN AIKMEL KABUPATEN LOMBOK TIMUR
}

\author{
Helmi Astuti ${ }^{1}$, Joni Rokhmat ${ }^{2}$, Sudirman ${ }^{3}$ \\ helmiastuti7@gamail.com \\ joni.fkip.unram@gmail.com \\ sudirmanmtr@gmail.com
}

\begin{abstract}
Abstrak: Tujuan penelitian ini adalah untuk mengetahui pengaruh lingkungan kerja dan motivMetode penelitian yang digunakan adalah metode kuantitatif, sedangkan teknik pengumpulan data yang digunakan dalam penelitian ini adalah kuesioner dan dokumentasi. Analisis data yang digunakan adalah analisis statistik deskriptif dan diuji dengan uji normalitas, homogenitas, multicollinearity, dan heteroskedastisitas. Untuk uji hipotesis menggunakan regresi linieritas sederhana dan uji regresi linieritas ganda. Hasil penelitian pada hipotesis pertama adalah Ada pengaruh yang signifikan lingkungan kerja terhadap kinerja guru yakni $t_{\text {hitung }}=3,784$ dengan nilai signifikansi $0,000<0,05$, maka $\mathrm{H}_{0}$ ditolah dan $\mathrm{H}_{\mathrm{a}}$ diterima. Besar hubungan atau pengaruh interpretasi (R) 0,445 dengan determinasi $R^{2} \quad 0,198$ atau $19,8 \%$. Hipotesis kedua adalah Ada pengaruh yang signifikan motivasi berprestasi terhadap kinerja guru yakni $t_{\text {hitung }}=4,580$ dengan nilai signifikansi $0,000<0,05$, maka $\mathrm{H}_{0}$ ditolah dan $\mathrm{H}_{\mathrm{a}}$ diterima. Besar hubungan atau pengaruh interpretasi (R) 0,515 dengan determinasi $\mathrm{R}^{2} 0,266$ atau $26,6 \%$. Hipotesis ketiga adalah Ada pengaruh yang signifikan lingkungan kerja dan motivasi berprestasi secara bersama-sama terhadap kinerja guru Madrasah Ibtidaiyah di Kecamatan Aikmel yakni $\mathrm{f}_{\text {hitung }} 15,959>\mathrm{f}_{\text {tabel }} 3,16$, maka $H_{a}$ diterima dan $H_{0}$ ditolak. Besar hubungan atau pengaruh berada pada kategori "cukup" mengacu pada interpretasi (R) 0,599 dengan determinasi $\mathrm{R}^{2} 0,359$ atau $35,9 \%$. Dapat dikatakan bahwa lingkungan kerja dan motivasi berprestasi memiliki peran penting dalam meningkatkan kinerja guru Madrasah Ibtidaiyah di Kecamatan Aikmel Kabupaten Lombok Timur.
\end{abstract}

Kata kunci: Lingkungan Kerja, Motivasi Berprestasi, Kinerja Guru, Madrasah Ibtidaiyah 


\begin{abstract}
The purpose of this study is to know effect working area and achievement motivation toward teacher's performance Islamic Elementary School in Aikmel Subdistrict of Regency East Lombok. The method used is quantitative method, while used the techniques collection data in this research is questionnaires and documentation. The data of analysis used is statistical descriptive analysis and tested with normality, homogeneity, multicollinearity, and heteroscedasticity. The hypothesis using to test a simple regression linearity and test multiple regression linearity. The results of the study on the first hypothesis is There a significant effect working area to teacher performance that is $t_{\text {arithmetic }}=3.784$ with significance value $0.000<0.05$, then $H_{0}$ rejected and $H_{a}$ accepted. The great relationship or effect interpretation of (R) 0.445 to determination $\mathrm{R}^{2}$ 0.198 or $19.8 \%$. The second hypothesis is There a significant effect of achievement motivation toward the teacher's performance that is $t_{\text {arithmetic }}=4.580$ with significance value $0.000<0.05$, then $\mathrm{H}_{0}$ rejected and $\mathrm{H}_{\mathrm{a}}$ accepted. The great relationship or effect interpretation of (R) 0.515 to determination $\mathrm{R}^{2} 0.266$ or $26.6 \%$. The third hypothesis is There is significant effect working area and achievement motivation together toward teacher's performance Islamic Elementary School in Aikmel Subdistrict that is $\mathrm{f}_{\text {arithmetic }} 15,959>\mathrm{f}_{\text {table }} 3,16$, then $\mathrm{H}_{0}$ rejected and $\mathrm{H}_{\mathrm{a}}$ accepted. The great relationship or effect interpretation are in the category of "enough" refers to the interpretation of $(R)$ 0.599 to determination $\mathrm{R}^{2} 0.359$ or $35.9 \%$. It can be said that the working area and achievement motivation be possessed important role in improving the teacher's performance of Islamic Elementary School in Aikmel Subdistrict of Regency East Lombok.
\end{abstract}

Key Word: Working Area, Achievement Motivation, Teacher's Performance, Islamic Elementary School

\section{PENDAHULUAN}

Undang-Undang Nomor 14 tahun 2005 Tentang Guru dan Dosen pasal 1 butir 1 menyatakan bahwa "guru adalah pendidik profesional dengan tugas utama mendidik, mengajar, membimbing, mengarahkan, melatih, menilai, dan mengevaluasi peserta didik pada pendidikan anak usia dini, pendidikan dasar, dan pendidikan menengah". Kemudian pasal 8 menyatakan bahwa, "Guru profesional harus memiliki kualifikasi akademik minimum sarjana atau diploma empat, menguasai kompetensi guru (pedagogik, profesional, sosial dan kepribadian), memiliki sertifikat pendidik, sehat jasmani dan rohani, serta memiliki kemampuan untuk mewujudkan tujuan pendidikan nasional". Dalam hal ini sangat jelas tuntutan profesionalitas guru. Profesionalitas yang dimilikinya akan meningkatkan kinerja yang dimiliki oleh seorang guru.

Uraian di atas menunjukkan bahwa guru merupakan salah satu unsur di bidang kependidikan yang berperan secara aktif dan menempatkan kedudukannya sebagai tenaga profesional untuk dapat meningkatkan mutu pendidikan di Indonesia. Dalam proses belajar-mengajar, guru ikut berperan dalam usaha pembentukan sumber daya manusia yang potensial di bidang pendidikan. Oleh karena itu, guru harus memiliki kemampuan khusus dalam bidang pendidikan dan pengajaran. Guru merupakan suatu profesi, yang berarti suatu jabatan yang memerlukan keahlian khusus dan tidak dapat dilakukan oleh sembarang orang di luar bidang pendidikan. Namun kenyataan menunjukkan bahwa mutu pendidikan di Indonesia masih terus bermasalah. 
Betapapun pemerintah telah berupaya meningkatkan mutu pendidikan melalui pemberian pelatihan kepada guru-guru, peningkatan penghasilan, pengadaan sarana dan prasarana bahkan juga telah diberikan beasiswa pendidikan untuk peningkatan jenjang pendidikan, namun belum memberikan pengaruh yang signifikan terhadap peningkatan mutu pendidikan. Kinerja guru yang diharapkan dapat mendongkrak kualitas dan relevansi pendidikan, dalam implementasinya di lapangan masih di pandang rendah. Hal ini dikarenakan banyaknya faktor yang mempengaruhinya dan saling berkaitan diantaranya disebabkan oleh guru yang kurang berkualitas, sarana dan prasarana sekolah yang kurang memadai dan tidak merata di seluruh Indonesia, lingkungan kerja sekolah kurang memadai, sekolah yang kurang memperhatikan tingkat kebutuhan pengguna, anggaran pendidikan yang kurang tepat sasaran, dan timbulnya berbagai masalah sosial kemasyarakatan, dan manajemen sekolah yang belum optimal.

Berdasarkan hasil wawancara dengan H. Sahudin, S.Ag, M.Pdi selaku Kepala bidang Pendidikan Agama Islam Kemenag Lotim mengungkapkan bahwa faktor penyebab rendahnya kualitas guru antara lain sebagai berikut: (1). Perbedaan dalam latar belakang pendidikan dan tingkat jabatan, (2). Sikap acuh/tidak peduli, misalnya kurangnya persiapan bahan ajar juga merupakan sikap acuh pendidik terhadap perkembangan pengetahuan sisiwa (3). Gaji guru, dengan gaji yang rendah, guru tidak memiliki motivasi mengajar yang memadai dalam melaksanakan tugas dan kewajibannya yang berat. Dampaknya dapat kita lihat dari rendanhya mutu pendidikan (4). Gagap adaptasi, guru tidak mampu menyesuaikan diri dengan siswa-siswanya.
Kinerja guru sangat menentukan terhadap kualitas pendidikan karena kinerja yang baik akan mendorong (mempercepat) tercapainya tujuan pendidikan Nasional. Sejalan dengan hal tersebut, Wibowo (2010) menjelaskan kinerja diartikan dengan: (1) sesuatu yang dicapai, (2) prestasi yang diperlihatkan, dan (3) kemampuan bekerja. Kaitan dengan penelitian ini, arti dari kinerja adalah prestasi yang diperlihatkan oleh seseorang. Secara terminologis, kinerja adalah ukuran seberapa baik orang melakukan pekerjaannya. Jadi, kinerja adalah tentang melakukan pekerjaan dan hasil yang dicapai dari pekerjaan tersebut.

Suastha (2006: 54) menjelaskan: (1) Kinerja merujuk pada penyelesaian tugas-tugas yang diberikan kepada karyawan, (2). "The accomplishment of goals is succesfull performance", artinya tujuan atas pencapaian keberhasilan kerja, (3) Kinerja berkaitan dengan perilaku yang dikaitkan dengan misi organisasi, (4) Kinerja merujuk pada hasil perilaku. Kinerja juga dilihat dari aspek non fisik, seperti kesetiaan, disiplin, kerjasama, inisiatif, kepemimpinan, dan sebagainya, dan (5) Kinerja merupakan fungsi dari kemampuan dan motivasi: "Performance $=$ ability * Motivation"

Gibson (dalam Supardi, 2013:31) ada tiga kelompok perilaku kinerja yaitu variabel individu, variabel organisasi, dan variabel psikologis. Variabel individu dikelompokkan pada sub variabel kemampuan dan keterampilan, latar belakang dan demografis. Sub variabel kemampuan dan keterampilan merupakan faktor utama yang mempengaruhi perilaku dan kinerja, variabel kemampuan dan keterampilan merupakan kompetensi kerja yang dimiliki seseorang. Terdapat lima jenis kompetensi menurut Gibson, yaitu: (1) Knowledge, adalah ilmu yang dimiliki 
individu dalam bidang pekerjaan tau area tertentu, (2) Skill, adalah kemampuan untuk unjuk kinerja fisik ataupun mental, (3) Self concep, adalah sikap individu, nilai-nilai yang dianut dan citra diri, (4) Traits, adalah karakteristik fisik dan respons yang konsisten atas situasi atau informasi tertentu, (5) Motives, adalah, pemekiran atau niat dasar konstan dan mendorong individu untuk bertindak atau berperilaku tertentu.

Berdasarkan pemaparan para ahli tersebut tentang kinerja guru khususnya di MI di Kecamatan Aikmel dapat ditingkatkan apabila komponenkomponen yang mempengaruhinya dapat diidentifikasi dan dioptimalkan untuk pencapaian tujuan pembelajaran. Berdasarkan hasil penelitian lebih lanjut, peneliti dapat menyimpulkan bahwa yang mempengaruhi kinerja guru adalah: (1) kedisiplinan guru, (2) lingkungan sekolah (lingkungan kerja), (3) motivasi berprestasi, (4) sebagian guru belum menguasai materi, metode, dan strategi pembelajaran, (5) tidak menguasai teknologi, (6) tidak menekuni profesinya secara utuh, dan (7) kemungkinan disebabkan oleh adanya perguruan tinggi swasta sebagai pencetak guru yang lulusannya asal jadi tanpa mempehitungkan outputnya kelak di lapangan.

Keinginan guru untuk bekerja dengan baik di sekolah memberikan pencapaian hasil kerja yang maksimal. Pada beberapa Madrsah Ibtidaiyah di Kecamatan Aikmel, peneliti menemukan kenyataan bahwa guru sering terlambat masuk ruang kelas karena sibuk dengan aktivitasnya yang tidak berhubungan dengan kegiatan proses pembelajaran. Pendapat di atas hendaknya dijadikan pelajaran dan bahan renungan bagi guru, untuk terus belajar dan melakukan perbaikan kinerjanya. Ukuran kinerja guru terlihat dari tanggung jawab dalam menjalankan amanah, profesi yang diembannya. Sikap ini akan dibarengi dengan rasa tanggung jawas guru dalam melaksanakan tugas. Sehingga kinerja guru dari waktu ke waktu akan meningkat.

Guru pada prinsipnya memiliki potensi yang cukup tinggi untuk berkreasi dan aktif guna meningkatkan kinerja tidak selalu berkembang secara wajar dan lancar. Walaupun guru bukan satu-satunya faktor penentu keberhasilan pendidikan tetapi kualifikasi sebagai cermin kualitas tenaga pengajar memberikan andil sangat besar pada kualitas pendidikan yang menjadi tanggung jawabnya. Kualitas guru atau kinerja yang rendah juga dipengaruhi oleh lingkungan kerja dan motivasi berprestasi guru.

Lingkungan kerja yang sejuk dan harmonis akan memberikan gairah dan inspirasi dalam bekerja. Hal ini didukung oleh hasil prasurvey peneliti pada Desember 2015, ditemukan bahwa para guru bekerja selain untuk mengharapkan imbalan baik material maupun non material, para guru juga menginginkan lingkungan kerja yang sesuai dengan harapan mereka seperti fasilitas yang standar dan lengkap, ada keterbukaan di sekolah, terdapat perhatian, dukungan, penghargaan, pendapatan yang yang layak dan adil. Lingkungan kerja kerja yang dimaksudkan yakni adanya lingkungan kerja baik secara fisik maupun dari lingkungan kerja non fisik.

Pertama Lingkungan kerja fisik adalah tempat kerja karyawan melakukan aktivitasnya. Lingkungan kerja fisik mempengaruhi semangat kerja dan emosi para karyawan. Menurut Robbins (2008) menyatakan bahwa "faktor-faktor lingkungan kerja fisik adalah: suhu, kebisingan, penerangan, dan mutu udara. Suhu adalah variabel dimana terdapat perbedaan individual yang besar. Dengan demikian untuk memaksimalkan produktivitas, adalah penting bahwa guru 
bekerja di suatu lingkungan dimana suhu diatur sedemikian rupa sehingga berada diantara rentang kerja yang dapat diterima setiap individu. Kebisingan menunjukkan bahwa suara-suara yang konstan atau dapat diramalkan pada umumnya tidak menyebabkan penurunan kinerja, sebaliknya efek dari suara-suara yang tidak dapat diramalkan memberikan dampak negatif dan menganggu konsentrasi guru.

Kedua Lingkungan kerja non fisik adalah semua keadaan yang terjadi yang berkaitan dengan hubungan kerja, baik hubungan dengan atasan maupun hubungan antara sesama rekan kerja, ataupun hubungan dengan bawahan. Lingkungan kerja non fisik ini juga merupakan kelompok lingkungan kerja yang tidak bisa diabaikan (Sedarmayanti, 2001:22).

Secara garis besar lingkungan sekolah sangatlah berpengaruh terhadap sebuah proses pembelajaran bagi anak didik, karena bagaimanapun lingkungan sekitar yang dengan sengaja digunakan sebagai alat dalam proses pendidikan. Pada dasarnya lingkungan mencakup: (1). Tempat (lingkungan fisik); keadaaan iklim, keadaan tanah, keadaan alam, (2) Kebudayaan (lingkungan budaya); dengan warisan budaya tertentu bahasa, seni, ekonomi, ilmu pengetahuan, pandangan hidup, keagamaan, dan (3) Kelompok hidup bersama (lingkungan sosial atau masyarakat); keluarga, kelompok bermain, desa, perkumpulan (Rahmawati, 2014).

Hal ini sejalan dengan pendapat Sedarmayanti (dalam Rustini, 2015:36) menjelaskan bahwa lingkungan kerja adalah semua keadaan berbentuk fisik yang terdapat di sekitar tempat kerja yang dapat mempengaruhi karyawan baik secara langsung maupun secara tidak langsung. Beberapa faktor yang yang dapat mempengaruhi terbentuknya suatu kondisi lingkungan kerja dikaitkan dengan kemampuan karyawan, yaitu: (1) Penerangan/cahaya di tempat kerja, (2) Temperatur di tempat kerja, (3) Kelembaban di tempat kerja, (4) Sirkulasi udara di tempat kerja, (5) Kebisingan di tempat kerja, (6) Getaran mekanis di tempat kerja, (7) Bau-bauan di tempat kerja, (8) Tata warna di tempat kerja, (9) Dekorasi di tempat kerja, dan (10) Musik di tempat kerja.

Beberapa faktor yang yang dapat mempengaruhi terbentuknya suatu kondisi lingkungan kerja dikaitkan dengan kemampuan seseorang, yaitu : (1) penerangan/cahaya di tempat kerja, (2) temperatur di tempat kerja, (3) kelembaban di tempat kerja, (3) sirkulasi udara di tempat kerja, (4) kebisingan di tempat kerja, (5) getaran mekanis di tempat kerja, (6) bau-bauan di tempat kerja, (7) tata warna di tempat kerja, (8) tata ruang/dekorasi di tempat kerja, (9) musik di tempat kerja, (10) keamanan di tempat kerja, (11) kebersihan.

Penciptaan iklim yang berorientasi pada prestasi dan mementingkan pekerja dapat memperlancar pencapaian hasil yang diinginkan. Dengan demikian jelaslah bahwa keberhasilan pendidikan yang terutama adalah faktor guru sebagai tenaga pendidik yang profesional. Salah satu hal yang patut dipertimbangkan adalah bagaimana upaya untuk meningkatkan kualitas guru adalah dengan cara menyiapkan fasilitas yang memadai dan lingkungan kerjanya yang nyaman. Dengan kinerja guru yang meningkat maka guru akan berusaha untuk meningkatkan profesi dan mutunya dengan demikian diharapkan keberhasilan pendidikan akan tercapai.

Faktor lain yang dapat berpengaruh terhadap kinerja adalah motivasi berprestasi. Hal ini didasarkan atas asumsi bahwa bekerja tanpa motivasi akan cepat bosan, karena tidak adanya unsur pendorong agar semangat kerja tetap stabil. Motivasi merupakan 
komoditi yang sangat diperlukan oleh semua orang termasuk guru. Motivasi diperlukan untuk menjalankan kehidupan, memimpin sekelompok orang dan mencapai tujuan organisasi. Motivasi berprestasi merupakan dorongan yang tumbuh dan berkembang dari dalam diri guru untuk melakukan pekerjaan sebaik mungkin sehingga tujuan akan tercapai. Motivasi berprestasi bisa terjadi jika guru mempunyai kebanggaan akan keberhasilan. Padahal tugas mengajar adalah tugas yang membanggakan dan penuh tantangan, sehingga guru-guru seharusnya mempunyai motivasi berprestasi.

Menurut Robbins (2015:127), kata motivasi berasal dari kata Latin "Movere" yang berarti dorongan atau daya penggerak. Selanjutnya diserap dalam bahasa Inggris motivation berarti pemberian motif, penimbulan motif atau hal yang menimbulkan dorongan atau keadaan yang menimbulkan dorongan. Motivasi juga berarti proses yang menjelaskan mengenai kekuatan, arah, dan ketekunan seseorang dalam upaya untuk mencapai tujuan. Jadi motivasi adalah usaha menuju setiap tujuan. Lebih

\section{METODE PENELITIAN \\ Tempat dan Waktu Penelitian}

Penelitian ini dilakukan pada Madrasah Ibtidaiyah di Kecamatan Aikmel Kabupaten Lombok Timur pada tahun pelajaran 2016/2017. Madrasah Ibtidaiyah di Kecamatan Aikmel berjumlah 20 Madrasah. Penelitian ini direncanakan pada bulan Juli sampai bulan Agustus 2016.

\section{Pendekatan dan Jenis Penelitian}

Penelitian ini menggunakan pendekatan ex post facto dengan metode kuantitatif. Metode kuantitatif adalah pendekatan yang mementingkan adanya variabel-variabel sebagai obyek penelitian dan varibel-variabel tersebut lanjut, tujuan pemberian motivasi menurut Hasibuan (1996:72) antara lain: (1) mendorong gairah dan semangat kerja bawahan, (2) meningkatkan moral dan kepuasan kerja karyawan; meningkatkan produktivitas kerja; (4) mempertahankan loyalitas dan kestabilan karyawan; (5) meningkatkan disiplin dan menurunkan tingkatan abseni karyawan; (6) menciptakan hubungan kerja yang baik; (7) meningkatkan kreativitas dan partisipasi karyawan; (8) meningkatkan kesejahteraan karyawan; mempertinggi rasa tanggung jawab karyawan terhadap tugas-tugasnya.

Berdasarkan uraian di atas dapat disimpulkan bahwa lingkungan kerja yang baik dan motivasi berprestasi dari guru merupakan faktor pendorong yang dapat meningkatkan kinerja guru. Dengan kata lain lingkungan kerja dan motivasi berprestasi dari guru berpengaruh terhadap kinerja guru. Hal inilah yang mendorong penulis tertarik untuk melakukan penelitian tentang: "Pengaruh Lingkungan Kerja dan Motivasi Berprestasi terhadap Kinerja Guru Madrasah Ibtidaiyah di Kecamatan Aikmel Kabupaten Lombok Timur".

harus didefinisikan secara operasionalisasi variabel masing-masing dan pemahaman dari luar. Sehubungan, dengan tujuan penelitian yang telah diungkapkan sebelumnya yaitu untuk meneliti pengaruh lingkungan kerja terhadap kinerja, pengaruh motivasi berprestasi terhadap kinerja dan pengaruh lingkungan kerja dan motivasi berprestasi terhadap kinerja, maka peneliti menggunakan jenis penelitian explanatory (penjelasan).

\section{Populasi dan Sampel Penelitian}

Peneliti menggunakan populasi terjangkau, di mana populasi ini adalah guru-guru pada 6 Madarasah Ibtidaiyah yang dipilih dari 20 Madrasah Ibtidaiyah 
di Kecamatan Aikmel, yaitu dua sekolah berakreditasi A, dua sekolah berakreditasi B, dan dua sekolah berakreditasi $\mathrm{C}$.

Teknik pengambilan sampel yaitu secara quota sampling (penarikan sampel secara jatah). Teknik sampling ini dilakukan dengan atas dasar jumlah atau jatah yang telah ditentukan peneliti. Sampel dalam penelitian ini terdiri atas 60 dari 130 orang guru di Madrasah Ibtidaiyah di Kecamatan Aikmel yang telah ditentukan. Dari 60 orang yang dijadikan sampel dalam penelitian ini, diharapkan akan memperoleh informasi

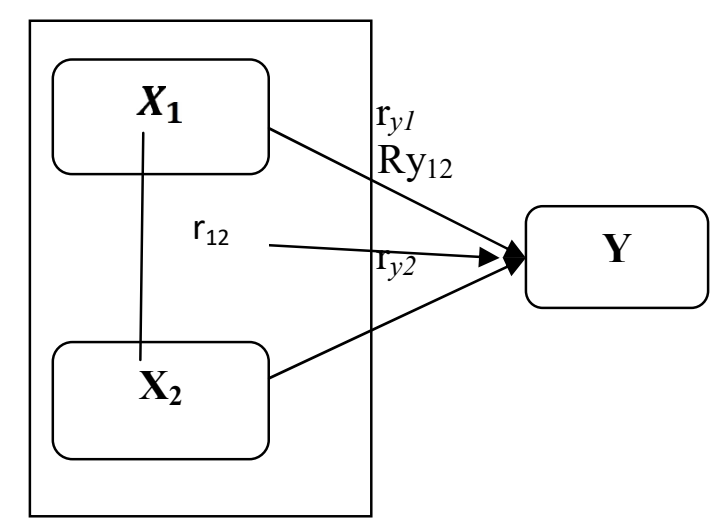

Gambar 1. Rancangan Penelitian

Keterangan:

$\mathrm{X}_{1}=$ Lingkungan kerja

$\mathrm{X}_{2}=$ Motivasi berprestasi

$\mathrm{Y}=$ Kinerja guru

\section{Instrumen Penelitian}

Alat pengumpulan data (instrumen) yang digunakan dalam penelitian ini adalah kuesioner atau daftar pertanyaan/pernyataan yang dipergunakan untuk mendapatkan data penelitian ini antara lain memanfaatkan daftar pertanyaan yang sudah standar dan tersedia, juga daftar pertanyaan/pernyataan yang dirancang sendiri atas bantuan dosen pembimbing. Butir-butir pertanyaan atau pernyataan dalam kuesioner dikembangkan berdasarkan atas konsep teori yang yang berarti untuk menerangkan dan memberikan penilaian terhadap ketiga variabel yang akan diteliti tersebut.

\section{Rancangan Penelitian}

Penelitian ini mencakup tiga buah variabel yang dibedakan menjadi dua variabel bebas dan satu variabel terikat. Yang termasuk variabel bebas dalam penelitian ini adalah Lingkungan Kerja $\left(\mathrm{X}_{1}\right)$ dan Motivasi Berprestasi $\left(\mathrm{X}_{2}\right)$, sedangkan variabel terikatnya adalah Kinerja Guru (Y) (Gambar 3.1). relevan dengan masing-masing variabel penelitian. Data yang ingin diperoleh dalam penelitian ini adalah data tentang pengaruh variabel bebas terhadap variabel terikat atau pengaruh lingkungan kerja dan motivasi berprestasi terhadap kinerja guru madrasah ibtidaiyah se Kecamatan Aikmel.

Adapun langkah-langkah dan teknik yang digunakan dalam pengumpulan data ini adalah sebagai berikut:

1) Untuk data lingkungan kerja diperoleh dari pendapat atau persepsi guru 
madrasah tentang lingkungan kerja (ruang kelas) tempat proses belajar mengajar berlangsung yang dijaring melalui pengisian kuesioner.

2) Untuk data motivasi berprestasi diperoleh dari pendapat atau persepsi guru madrasah tentang motivasi berprestasi guru yang dijaring melalui pengisian kuesioner.

3) Untuk data kinerja guru madrasah diperoleh dari pendapat atau penilaian guru dan dilengkapi oleh penilaian Kepala Madrasah tentang bagaimana kinerja masing-masing guru madrasah ibtidaiyah yang menjadi sampel.

\section{Teknik Analisis Data}

Analisis data adalah kegiatan yang bertujuan untuk menyederhanakan data ke dalam bentuk yang lebih mudah dibaca dan diinterpretasikan. Dalam proses ini statistik dipergunakan untuk menyederhanakan data. Analisis data yang digunakan dalam penelitian ini adalah analisis statistik deskriptif, uji hipotesis dilakukan meliputi uji prasyarat yakni normalitas, homogenitas, multicollinearitas, dan heteroskedastisitas, dan untuk analisis infersial yang dilakukan yakni uji regresi linear sederhana dan uji regresi linear ganda dengan kriteria pengujian jika sig. $\leq 0,05$ maka ada hubungan yang signifikan (Ha diterima), sebaliknya jika nilai sig. $>0,05$ maka tidak ada hubungan yang signifikan (Ho diterima). Untuk mengetahui besaran pengaruh dilakukan interpretasi R2 model regresi berganda adalah perlu. Dalam uji statistik masih diperlukan untuk mengetahui besarnya koefisien determinasi (R2) guna mengukur seberapa jauh kemampuan model dalam menerangkan variasi variabel terikat.

\section{Hasil Penelitian dan Pembahasan Deskripsi Data}

Deskripsi data hasil penelitian mencakup penyebaran data pada responden guru Madrasah Ibtidaiyah di Kecamatan Aikmel. Variabel yang diukur yaitu kinerja guru, lingkungan kerja, dan motivasi berprestasi. Penilaian ini didasarkan pada total jawaban responden pada tiap indikator variabel penelitian. Lebih lanjut hasil perhitungan tersebut akan digunakan untuk mendeskripsikan respon subjek terhadap variabel penelitian. Deskripsi data dalam penelitian ini meliputi mean, median, standar deviasi, nilai terendah, nilai tertinggi, varian, rentang nilai, taraf kesalahan, modus, kurtosis, dan positif skewness. Data dalam penelitian ini diolah dengan menggunakan metode statistik deskriptif. Metode statistik deskriptif lebih berhubungan dengan pengumpulan dan peringkasan data, serta penyajian hasil peringkasan tersebut. Uraian hasil perhitungan deskriptif dijelaskan sebagai berikut.

Tabel 1. Hasil Analisis Deskriptif Penelitian Penyebaran Angket

\begin{tabular}{|lllll|}
\hline Variabel & Max & Min & $\bar{X}$ & SD \\
\hline Kinerja Guru & 97 & 65 & 79.01 & 6.55 \\
Lingkungan Kerja & 96 & 52 & 70.22 & 7.26 \\
Motivasi Berprestasi & 83 & 47 & 68.72 & 6.68 \\
\hline
\end{tabular}

Berdasarakan data tabel 1, variabel kinerja guru diperoleh nilai maksimal yakni 97 dan nilai minimal yakni 65 pada rata-rata 79,01 dengan standar deviasi atau simpangan baku berada pada kisaran
6,55 . Untuk melihat kategori kinerja guru dari 60 responden yakni 46 orang atau $76,67 \%$ berada pada kotegori tinggi, sedangkan untuk kategori rendah yakni 14 orang atau $23,33 \%$ dari 60 responden. 
Adapun bentuk data histogram variabel

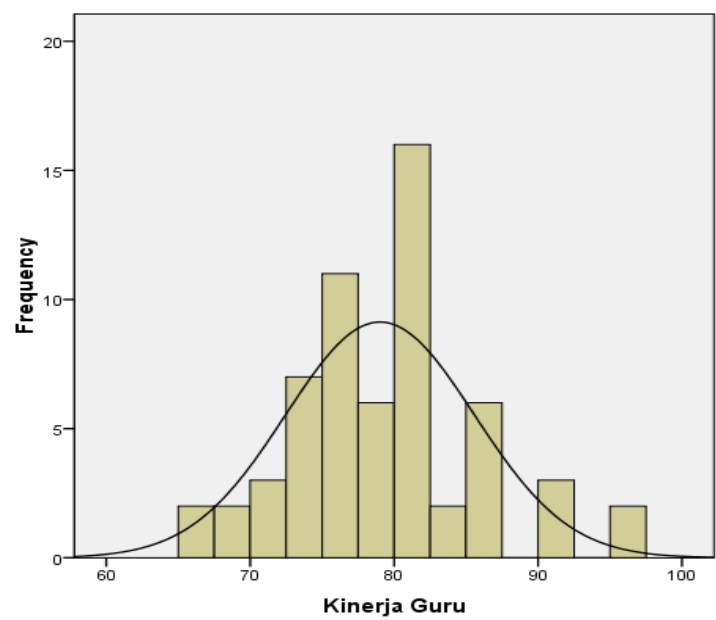

Gambar 1. Histogram Variabel Kinerja Guru kinerja guru sebagai berikut:

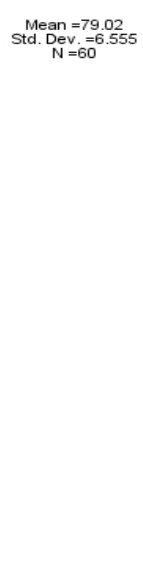

Tabel 1, variabel lingkungan kerja diperoleh nilai maksimal yakni 96 dan nilai minimal yakni 52 pada rata-rata 70,22 dengan standar diviasi atau simpangan baku berada pada kisaran 7,26 . Untuk melihat kategori lingkungan

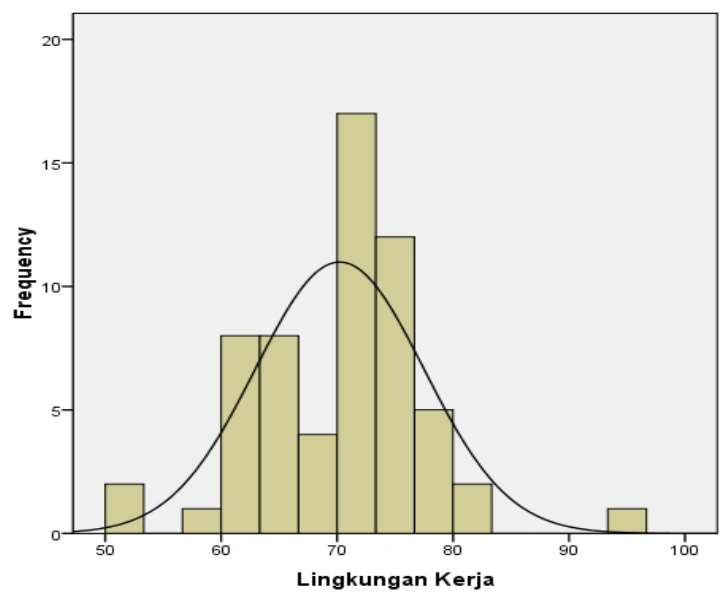

kerja dari 60 responden, 7 orang atau $11,67 \%$ berada pada kategori tinggi sedangkan pada kategori rendah yakni 53 orang atau $88,33 \%$. Adapun bentuk data histogram variabel lingkungan kerja sebagai berikut:

Gambar 2. Histogram Variabel Lingkungan Kerja

Tabel 1, variabel motivasi berprestasi diperoleh nilai maksimal yakni 83 dan nilai minimal yakni 47 pada rata-rata 68,72 dengan standar deviasi atau simpangan baku berada pada kisaran
6,68. Untuk melihat kategori motivasi berprestasi dari 60 responden, 5 orang atau $8,33 \%$ berada pada kategori tinggi sedangkan pada kategori rendah yakni 54 orang atau $90 \%$, adapun untuk kategori 
sangat rendah yakni 1 orang atau 1,67\%. Adapun bentuk data histogram variabel

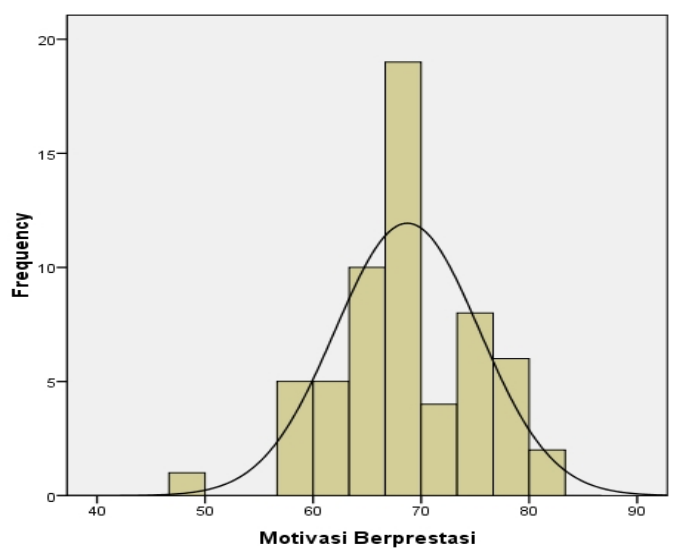

motivasi berprestasi sebagai berikut:<smiles>[As]=[As]</smiles>

Gambar 3. Histogram Variabel Motivasi Berprestasi

\section{Uji Persyaratan}

Tujuan awal dari penelitian ini yaitu menganalisi hipotesa tentang ada tidaknya pengaruh terkait dengan variabel bebas lingkungan kerja $\left(\mathrm{X}_{1}\right)$ dan motivasi berprestasi $\left(\mathrm{X}_{2}\right)$ dengan variabel terikat kinerja guru (Y). Hipotesis tersebut dilakukan terhadap responden guru Madrasah Ibtidaiyah di Kecamatan Aikmel. Dalam hal ini, uji statistik yang digunakan adalah uji regresi dan untuk memenuhi asumsi data terdiri dari normal, bersifat homogen, multicollinearitas, dan tidak bersifat heterogenesitas.

Sebelum melakukan uji hipotesis, akan dilakukan uji asumsi klasik yaitu uji normalitas dan uji homogenitas atau uji linieritas. Hasil uji asumsi klasik dapat dilihat di bawah ini.

\section{Uji Normalitas}

Uji asumsi ini bertujuan untuk mengetahui apakah data yang diperoleh dari penelitian di lapangan mempunyai distribusi normal. Penelitian ini menggunakan uji Kolmogorov Smirnov untuk menguji distribusi data. Jika tingkat signifikan (sig.) dari uji Kolmogorov Smirnov lebih dari 0.05 maka data tersebut dikatakan berdistribusi normal.

Berdasarkan hasil uji normalitas di atas, terlihat nilai Asymp. Sig. (2-tailed) menggunakan uji One-Sample Kolmogorov-Smirnov Test pada variabel kinerja guru diperoleh nilai 0.078 , variabel motivasi berprestasi 0,709 , dan variabel lingkungan kerja 0,526 . Sesuai dengan hasil uji normalitas ke tiga variabel pada aras signifikan $0,05 \%$, dapat dikatakan ke tiga variabel tersebut berdistribusi normal. Selain menguji normalitas tiap-tiap variabel, dilihat pada Unstandardized Residual diperoleh nilai 0,583, hal ini menunjukkan secara keseluruhan data tersebut berdistribusi normal pada aras signifikan $0,05 \%$. Adapun grafik histogram uji normalitas variabel kinerja lingkungan dan motivasi berprestasi terhadap kinerja guru sebagai berikut. 


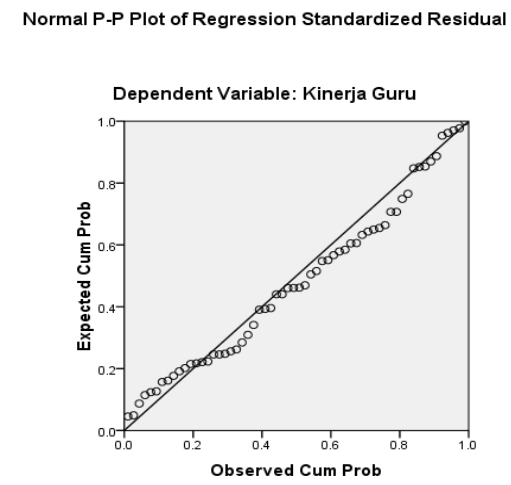

Gambar 4. Distribusi Data Normalitas

Adapun diagram normalitas variabel Y pada regression Standardized Residual sebagai berikut:

Histogram

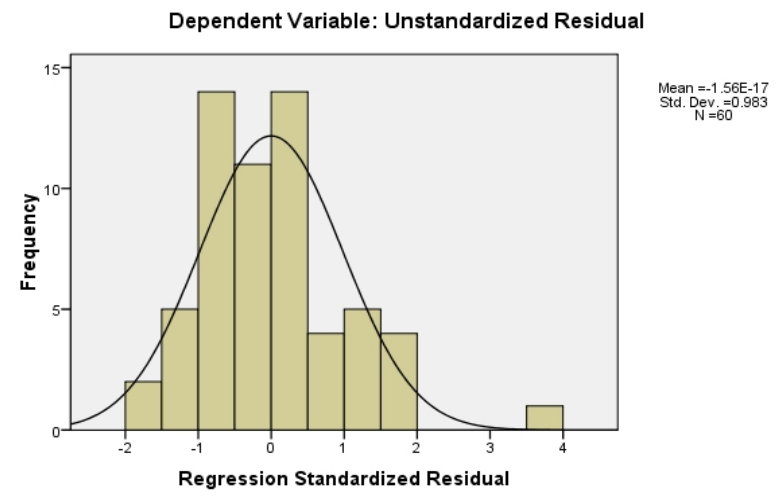

Gambar 5. Histogram Data Normalitas

\section{Uji Homogenitas}

Uji homogenitas digunakan untuk mengetahui keseragaman data responden dengan cara membandingkan varian terbesar dengan varian terkecil antara variabel lingkungan kerja $\left(\mathrm{X}_{1}\right)$, variabel motivasi kerja $\left(\mathrm{X}_{2}\right)$ dengan kinerja guru $(\mathrm{Y})$. adapun rumus yang digunakan yakni $\mathrm{f}_{\mathrm{h}}=\frac{\mathrm{v}}{\mathrm{v}} \mathrm{t}_{\mathrm{t}} \quad$ dengan ketentuan jika $f_{h}$ lebih kecil dibanding $\mathrm{f}_{\mathrm{t}_{i}}$ maka data tersebut homogen, namun jika $\mathrm{f}_{\mathrm{t}_{\mathrm{i}}}$ lebih besar dibanding dengan $f_{h}$ maka data tersebut heterogen. Adapun untuk menguji homogenitas ketiga variabel tersebut yakni variabel lingkungan kerja terhadap variabel kinerja guru dan variabel motivasi berprestasi dengan kinerja guru dapat diuraikan sebagai berikut:

Tabel 2. Uji Homogenitas Varian Variabel Lingkungan Kerja Terhadap Kinerja Guru 


\begin{tabular}{|c|c|c|}
\hline & $\begin{array}{c}\text { Variabel } \\
\text { Lingkungan } \\
\text { Kerja } \mathrm{X}_{1}\end{array}$ & $\begin{array}{c}\text { Variabel Kinerja } \\
\text { Guru Y }\end{array}$ \\
\hline Varian & 52,74 & 42,96 \\
\hline $\mathrm{N}$ & 60 & 60 \\
\hline
\end{tabular}

$\mathrm{f}_{\mathrm{h}} \quad=\frac{\text { Varian lingkungan kerja }}{\text { Varian Kinerja Guru }}=\frac{52.74}{42.96}=1.227$

Berdasarkan hasil perhitungan di atas, di ketahui $\mathrm{f}_{\mathrm{h}} \quad 1.227$ pada aras signifikan $0.05 \%$ dengan derajat bebas pembilang $(\mathrm{db}) \quad \mathrm{n}-1=60-1=59$ dan penyebut $(\mathrm{db}) \mathrm{n}-1=60-1=59$ sehingga diperoleh $\mathrm{f}_{\mathrm{t}_{\mathrm{i}}}$ 1,52. Dengan demikian $\mathrm{f}_{\mathrm{h}} \quad 1.227<\mathrm{f}_{\mathrm{t}_{\mathrm{i}}} \quad 1.52$, berdasarkan uji signifikan tersebut dapat dikatakan bahwa data variabel lingkungan kerja terhadap kinerja guru bersifat homogen. Data tersebut dikatakan homogen dikarenakan $\mathrm{f}_{\mathrm{h}} \quad$ lebih kecil dari $\mathrm{f}_{\mathrm{t}_{\mathrm{i}}}$ sehingga data tersebut dikatakan homogin. Dengan kata lain, semakin kecil koefisien varian maka data tersebut semakin

Tabel 3. Uji Homogenitas Varian Variabel Motivasi Berprestasi Terhadap Kinerja Guru

\begin{tabular}{|c|c|c|}
\hline & $\begin{array}{c}\text { Variabel } \\
\text { Motivasi } \\
\text { Berprestasi } \mathrm{X}_{2}\end{array}$ & $\begin{array}{c}\text { Variabel Kinerja } \\
\text { Guru Y }\end{array}$ \\
\hline Varian & 44,68 & 42,96 \\
\hline $\mathrm{N}$ & 60 & 60 \\
\hline
\end{tabular}

$\mathrm{f}_{\mathrm{h}}=\frac{\text { Varian motivasi berprestasi }}{\text { Varian Kinerja Guru }}=\frac{44,68}{42.96}=1,040$

Berdasarkan hasil perhitungan di atas, diketahui $\mathrm{f}_{\mathrm{h}} \quad 1.040$ pada aras signifikan $0.05 \%$ dengan derajat bebas pembilang $(\mathrm{db}) \quad \mathrm{n}-1=60-1=59$ dan penyebut (db) $\mathrm{n}-1=60-1=59$ sehingga diperoleh $\mathrm{f}_{\mathrm{t}_{\mathrm{i}}}$ 1,52. Dengan demikian $\mathrm{f}_{\mathrm{h}} \quad 1.040<\mathrm{f}_{\mathrm{t}} \quad 1.52$, berdasarkan uji signifikan tersebut dapat dikatakan bahwa data variabel motivasi berprestasi terhadap kinerja guru bersifat homogen. Data tersebut dikatakan homogen dikarenakan $\mathrm{f}_{\mathrm{h}} \quad$ lebih kecil dari $\mathrm{f}_{\mathrm{t}_{\mathrm{i}}} \quad$ l sehingga data tersebut dikatakan homogen. Dengan kata lain, semakin kecil koefisien varian maka data tersebut semakin homogen.

\section{Uji Multicollinearitas}

Uji multikolinearitas bertujuan untuk menguji apakah dalam model regresi ditemukan adanya korelasi antar variabel bebas. Model regresi yang baik seharusnya tidak terjadi di antara variabel bebas. Dalam penelitian ini gejala multikolinearitas dilihat dari nilai tolerance dan Variance Inflation Factor (VIF). Adapun uji multikolinearitas menggunakan program SPSS sebagai berikut. 
Tabel 4. Uji Multicollinearitas

\section{Coefficients $^{\mathrm{a}}$}

\begin{tabular}{|l|r|r|r|r|r|}
\hline \multirow{2}{*}{ Model } & \multicolumn{2}{|c|}{$\begin{array}{c}\text { Unstandardized } \\
\text { Coefficients }\end{array}$} & & \multicolumn{2}{c|}{$\begin{array}{c}\text { Collinearity } \\
\text { Statistics }\end{array}$} \\
\cline { 2 - 3 } & B & $\begin{array}{c}\text { Std. } \\
\text { Error }\end{array}$ & Sig. & $\begin{array}{c}\text { Toler } \\
\text { ance }\end{array}$ & VIF \\
\hline $1 \quad$ (Constant) & 30.421 & 8.643 & .001 & & \\
$\begin{array}{l}\text { Lingkungan } \\
\text { Kerja } \\
\text { Motivasi } \\
\text { Berprestasi }\end{array}$ & .289 & .100 & .006 & .912 & 1.097 \\
\hline
\end{tabular}

a. Dependent Variable: Kinerja Guru

Berdasarkan pada tabel 4.10 diketahui nilai VIF sebesar 1.097 dan nilai tolerance sebesar 0,912. Dengan demikian, pada hasil analisis tolerance dan VIF lebih kecil dari 5, ini menunjukkan bahwa tidak terdapat Multicollinearity pada variabel lingkungan kerja yang berkorelasi sempurna atau mendekati sempurna dengan variabel motivasi kerja.

\section{Uji Heteroskedastisitas}

Untuk mendeteksi ada atau tidak heteroskedastisitas dapat digunakan uji

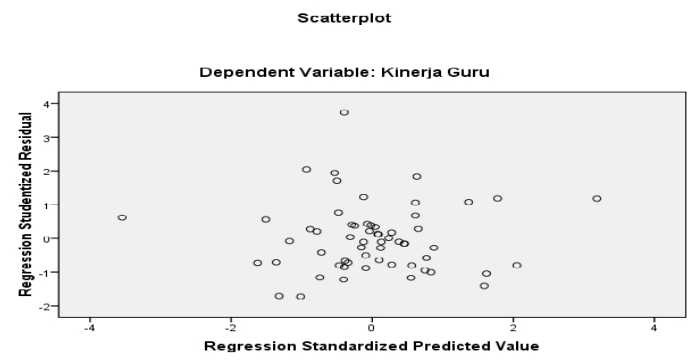

Gambar 6. Uji Heteroskedastisitas

\section{Pengujian Hipotesis}

Berdasarkan hasil uji prasyarat data yang telah dilakukan yakni uji normalitas, homogenitas, multicollinearitas, dan heteroskedasititas. Diperoleh hasil uji normalitas yakni diperoleh hasil unstandardised residual $0,583>0,05$ yang menunjukkan data responden bersdistribusi normal; hasil uji homogenitas menunjukkan bahwa $\mathrm{f}_{\mathrm{h}}$ rank corelation spearman, yaitu dengan mengkorelasikan antara variabel bebas dengan absolut residual. Bila signifikansi hasil korelasi lebih besar dari 0,05 (5\%), maka tidak terjadi heteroskedastisitas. Diketahui nilai Unstandardized Residual Absolut yakni 0,100 pada aras signifikan 0,05 , maka dapat dikatakan bahwa tidak terjadi heteroskedastisitas antara variabel bebas lingkungan kerja dan motivasi berprestasi pada absolute residual disebabkan 0,100>0,05. Diagram gambar Unstandardized Residual Absolut ditampilkan sebagai berikut. dari tiap-tiap koefisiensi varian lebih kecil dari $\mathrm{f}_{\mathrm{t}_{\mathrm{i}}}=1,52$ sehingga data tersebut bersifat homogen; hasil uji multicollinearitas, diperoleh nilai VIF 1,097 dan tolerance 0,912 lebih besar dari 0,05 sehingga data tersebut terdapat multicollinearisitas; dan uji heteroskedasititas menunjukkan hasil absolute residual $0,100>0,05$ yang 
berarti data tersebut tidak terdapat heteroskedastisitas.

Hasil keempat uji tersebut menyatakan bahwa data memenuhi syarat untuk diuji dengan regresi linear sederhana dan regresi linear ganda. Uji linear sederhana adalah untuk menguji hipotesis nomer 1 dan 2 sedangkan uji regresi linear ganda digunakan untuk menguji hipotesis nomer 3. Adapun pengujian hipotesis sebagai berikut.

1. Pengaruh lingkungan kerja $\left(\mathrm{X}_{1}\right)$ terhadap kinerja guru $(\mathrm{Y})$
Hipotesis pertama yang diajukan dalam penelitian ini menyatakan bahwa ada pengaruh lingkungan kerja $\left(\mathrm{X}_{1}\right)$ terhadap kinerja guru (Y). untuk mengetahui pengaruh lingkungan kerja terhadap kinerja guru, telah dilakukan pengujian hipotesis uji regresi sederhana melalui alat bantu Program SPSS. adapun hasil uji hipotesis dengan menggunakan program SPSS sebagai berikut.

Tabel 5. Signifikansi Pengaruh Lingkungan Kerja terhadap Kinerja Guru

\section{ANOVA $^{\mathrm{B}}$}

\begin{tabular}{|l|r|r|r|c|c|}
\hline \multicolumn{1}{|c|}{ Model } & $\begin{array}{c}\text { Sum of } \\
\text { Squares }\end{array}$ & Df & $\begin{array}{c}\text { Sean } \\
\text { Square }\end{array}$ & F & Sig. \\
\hline $1 \quad \begin{array}{l}\text { Regressi } \\
\text { on }\end{array}$ & 501.885 & 1 & 501.88 & 14.318 & $.000^{\mathrm{a}}$ \\
Residual & 2033.098 & 58 & 35.053 & & \\
Total & 2534.983 & 59 & & & \\
\hline
\end{tabular}

a. Predictors: (Constant),

Lingkungan Kerja

b. Dependent Variable: Kinerja

Guru

Tabel 5. menjelaskan apakah ada pengaruh yang signifikan antara lingkungan kerja terhadap kinerja guru. Berdasarkan output pada tabel tersebut, terlihat bahwa $\mathrm{f}_{\mathrm{h}} \quad=14.318$ dengan aras signifikan atau probalitas
$0.000<0.05$, maka model regresi dapat dipakai untuk memprediksi variabel kinerja guru. Selanjutnya untuk mengetahui persamaan regresi atau nilai coefficients variabel lingkungan kerja terhadap kinerja guru sebagai berikut:

Tabel 6. Persamaan Regresi Variabel Lingkungan Kerja terhadap Kinerja Guru

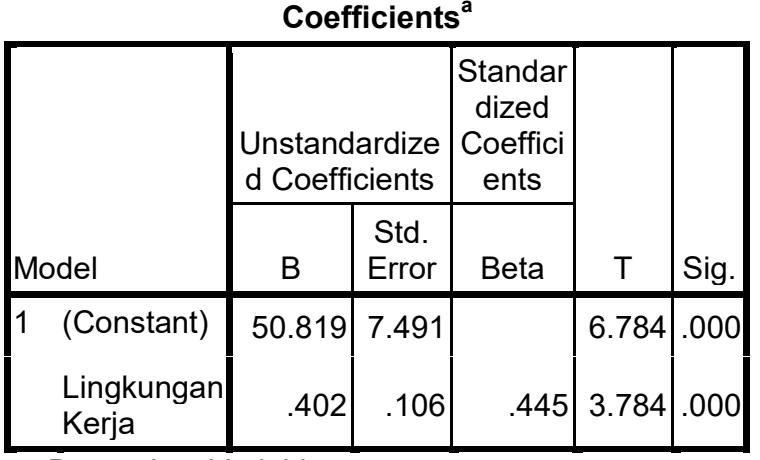

a. Dependent Variable:

Kinerja Guru

Tabel 6. menjelaskan pada kolom B (constant) adalah 50,815, sedangkan nilai variabel lingkungan kerja 0,402 sehingga persamaan regresinya $\mathrm{Y}=\mathrm{a}+\mathrm{bX} \mathrm{X}_{1}$ 
$(50,815+0,402)$. Koefisien b dinamakan koefisien arah regresi yang menyatakan perubahan rerata variabel kinerja guru (Y) untuk setiap perubahan variabel lingkungan kerja (X) sebesar satu satuan. Perubahan ini merupakan pertambahan jika $b$ ditandai dengan nilai positif dan akan mengalami penurunan jika $b$ ditandai dengan nilai negatif. Berdasarkan nilai constant sebesar 50,815 dan nilai variabel lingkungan kerja sebesar 0,402, artinya ada peningkatan yang positif antara variabel lingkungan kerja terhadap kinerja guru. Lebih lanjut, selain menguji persamaan regresi sederhana pada output di atas, diketahui nilai $t_{h}=3,784$ dengan nilai signifikansi $0,000<0,05$, maka $\mathrm{H}_{0}$ ditolah dan $\mathrm{H}_{\mathrm{a}}$ diterima. Dengan demikian, dapat dikatakan bahwa ada pengaruh yang signifikan variabel lingkungan kerja terhadap kinerja guru. Lebih lanjut, untuk mengetahui pengaruh lingkungan kerja terhadap kinerja guru melalui nilai $\mathrm{R}$ sebagai berikut.

Tabel 7. Model Summary Pengaruh Lingkungan Kerja Terhadap Kinerja Guru

Model Summary

\begin{tabular}{|l|c|r|r|r|}
\hline Model & $\mathrm{R}$ & $\mathrm{R}$ Square & $\begin{array}{c}\text { Adjusted R } \\
\text { Square }\end{array}$ & $\begin{array}{c}\text { Std. Error of } \\
\text { the Estimate }\end{array}$ \\
\hline 1 & $.445^{\mathrm{a}}$ & .198 & .184 & 5.921 \\
\hline
\end{tabular}

a. Predictors: (Constant), Lingkungan Kerja

Tabel 7. menjelaskan besarnya nilai korelasi atau hubungan $(\mathrm{R})$ yaitu sebesar 0,445 dan dijelaskan besarnya persentase pengaruh variabel lingkungan kerja terhadap variabel kinerja guru yang disebut koefisien determinasi yang merupakan hasil dari penguadratan $\mathrm{R}$. Berdasarkan output tersebut diperoleh koefisien determinasi (R2) sebesar 0.198 yang mengandung pengertian bahwa pengaruh variabel lingkungan kerja terhadap kinerja guru adalah sebesar $19,8 \%$ sedangkan sisanya dipengaruhi oleh variabel lain.
2. Pengaruh Motivasi Berprestasi $\left(\mathrm{X}_{2}\right)$ terhadap Kinerja Guru (Y)

Hipotesis kedua yang diajukan dalam penelitian ini menyatakan bahwa ada pengaruh motivasi berprestasi $\left(\mathrm{X}_{2}\right)$ terhadap kinerja guru (Y). Untuk mengetahui pengaruh motivasi berprestasi terhadap kinerja guru, telah dilakukan pengujian hipotesis uji regresi sederhana melalui alat bantu Program SPSS. Adapun hasil ujis hipotesis t-tes dengan menggunakan program SPSS sebagai berikut.

Tabel 8. Signifikansi Pengaruh Motivasi Berprestasi terhadap Kinerja Guru

ANOVA $^{\mathrm{D}}$

\begin{tabular}{|c|c|c|c|c|c|}
\hline Model & $\begin{array}{c}\text { Sum of } \\
\text { Squares }\end{array}$ & Df & $\begin{array}{c}\text { Mean } \\
\text { Square }\end{array}$ & F & Sig. \\
\hline 1 Regression & 673.314 & 1 & 673.31 & 20.977 & $.000^{\mathrm{a}}$ \\
& & 4 & & \\
Residual & 1861.669 & 58 & 32.098 & & \\
Total & 2534.983 & 59 & & & \\
\hline
\end{tabular}

a. Predictors: (Constant), Motivasi

Berprestasi 
ANOVA $^{\mathrm{D}}$

\begin{tabular}{|l|r|r|r|c|c|}
\hline Model & $\begin{array}{c}\text { Sum of } \\
\text { Squares }\end{array}$ & Df & $\begin{array}{c}\text { Mean } \\
\text { Square }\end{array}$ & F & Sig. \\
\hline $1 \quad$ Regression & 673.314 & 1 & 673.31 & 20.977 & $.000^{\mathrm{a}}$ \\
& & 4 & & \\
Residual & 1861.669 & 58 & 32.098 & & \\
Total & 2534.983 & 59 & & & \\
\hline
\end{tabular}

b. Dependent Variable: Kinerja

Guru

Tabel 8. menjelaskan apakah ada pengaruh yang signifikan antara motivasi berprestasi terhadap kinerja guru. Berdasarkan output pada tabel tersebut, terlihat bahwa $\mathrm{f}_{\mathrm{h}} \quad=20,977$ dengan aras signifikan atau probalitas
$0.000<0.05$, maka model regresi dapat dipakai untuk memprediksi variabel kinerja guru. Selanjutnya untuk mengetahui persamaan regresi atau nilai coefficients variabel motivasi berprestasi terhadap kinerja guru sebagai berikut:

Tabel 9. Persamaan Regresi Variabel Motivasi Berprestasi terhadap Kinerja Guru

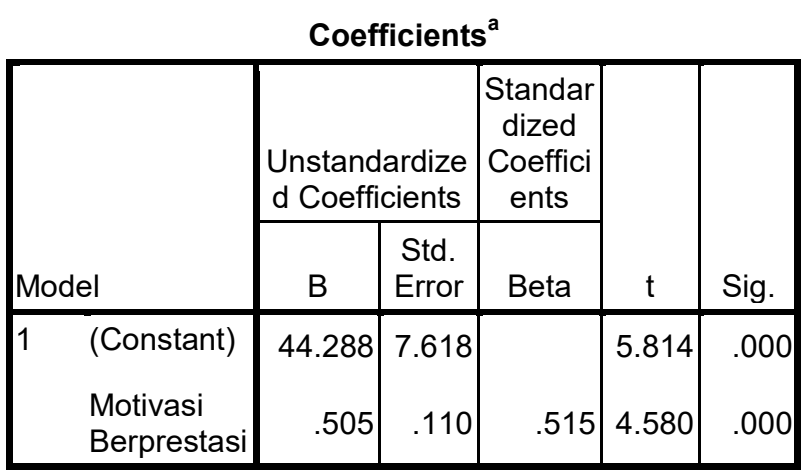

a. Dependent Variable:

Kinerja Guru

Tabel 9. menjelaskan pada kolom B (constant) adalah 44,288, sedangkan nilai variabel lingkungan kerja 0,505 sehingga persamaan regresinya $\mathrm{Y}=\mathrm{a}+\mathrm{bX}$ $(44,288+0,505)$. Berdasarkan nilai constant sebesar 44,288 dan nilai variabel motivasi berprestasi sebesar 0,505 , artinya ada peningkatan yang positif antara variabel motivasi berprestasi terhadap kinerja guru. Lebih lanjut, selain menguji persamaan regresi sederhana pada output di atas, diketahui nilai $t_{h}=4,580$ dengan nilai signifikansi $0,000<0,05$, maka $\mathrm{H}_{0}$ ditolah dan $\mathrm{H}_{a}$ diterima. Dengan demikian, dapat dikatakan bahwa ada pengaruh yang signifikan variabel lingkungan kerja terhadap kinerja guru. Lebih lanjut, untuk mengetahui pengaruh motivasi berprestasi terhadap kinerja guru melalui nilai R sebagai berikut. 
Tabel 10. Model Summary Pengaruh Motivasi Berprestasi terhadap Kinerja Guru Model Summary

\begin{tabular}{|l|l|r|r|r|}
\hline Model & $\mathrm{R}$ & $\mathrm{R}$ Square & $\begin{array}{c}\text { Adjusted R } \\
\text { Square }\end{array}$ & $\begin{array}{l}\text { Std. Error of } \\
\text { the Estimate }\end{array}$ \\
\hline 1 & $.515^{\mathrm{a}}$ & .266 & .253 & 5.665 \\
\hline
\end{tabular}

a. Predictors: (Constant), Lingkungan Kerja

Tabel 10 menjelaskan besarnya nilai korelasi atau hubungan $(\mathrm{R})$ yaitu sebesar 0,515 dan dijelaskan besarnya persentase pengaruh variabel motivasi berprestasi terhadap variabel kinerja guru yang disebut koefisien determinasi yang merupakan hasil dari penguadratan $\mathrm{R}$. Berdasarkan output tersebut diperoleh koefisien determinasi (R2) sebesar 0.266 yang mengandung pengertian bahwa pengaruh variabel motivasi berprestasi terhadap kinerja guru adalah sebesar $26.6 \%$ sedangkan sisanya dipengaruhi oleh variabel lain.

3. Pengaruh Lingkungan Kerja $\left(\mathrm{X}_{1}\right)$ dan Motivasi Berprestasi $\left(\mathrm{X}_{2}\right)$ terhadap Kinerja Guru (Y)
Hipotesis ketiga yang diajukan dalam penelitian ini menyatakan bahwa ada pengaruh lingkungan kerja $\left(\mathrm{X}_{1}\right)$ dan motivasai berprestasi $\left(\mathrm{X}_{2}\right)$ secara bersama-sama terhadap kinerja guru $(\mathrm{Y})$. untuk mengetahui pengaruh variabel $\mathrm{X}_{1}$ dan $\mathrm{X}_{2}$ secara bersama-sama terhadap variabel $\mathrm{Y}$, telah dilakuakan pengujian hipotesis uji regerisi linieritas ganda dengan menggunakan program SPSS maupun dalam bentuk manual. Adapun hasil uji hipotesis dengan menggunakan program SPSS sebagai berikut.

Untuk mengetahui secara signifikan ringkasan tingkat hubungan yang mempengaruhi variabel $X_{1}$ dan $X_{2}$ terhadap varibel $Y$. dapat dilihat pada tabel berikut.

Tabel 11. Uji Signifikansi Linieritas Ganda Pengaruh Lingkungan Kerja $\left(\mathrm{X}_{1}\right)$ dan Motivasi Berprestasi $\left(\mathrm{X}_{2}\right)$ terhadap Kinerja Guru $(\mathrm{Y})$

ANOVA $^{\text {b }}$

\begin{tabular}{|l|r|r|r|r|r|}
\hline Model & $\begin{array}{c}\text { Sum of } \\
\text { Squares }\end{array}$ & df & $\begin{array}{c}\text { Mean } \\
\text { Square }\end{array}$ & $\mathrm{F}$ & Sig. \\
\hline $\begin{array}{l}\text { Regressi } \\
\text { on }\end{array}$ & 909.951 & 2 & 454.97 & 15.959 & $.000^{\mathrm{a}}$ \\
$\quad$ Residual & 1625.032 & 57 & 28.509 & & \\
\hline Total & 2534.983 & 59 & & & \\
\hline
\end{tabular}

a. Predictors: (Constant), Motivasi Berprestasi,

Lingkungan Kerja

b. Dependent Variable:

Kinerja Guru

Berdasarkan tabel 11. di atas mengindikasikan bahwa secara statistik sangat signifikan dengan nilai $\mathrm{f}_{\mathrm{h}} \quad 15,959$ untuk derajat kebebasan $\mathrm{db}$ pembilang $=\mathrm{m}, \mathrm{db}$ penyebut $=\mathrm{n}-\mathrm{m}-1=60$ 2-1=57 sehingga diperoleh $\mathrm{f}_{\mathrm{t}_{\mathrm{i}}} \quad 3,16$ pada aras signifikan $0,05 \%$ maka dengan ketentuan pengujian hipotesis $\mathrm{f}_{\mathrm{h}} \quad 15,959>\mathrm{f}_{\mathrm{t}_{\mathrm{i}}} \quad 3,16, H_{a}$ diterima dan $H_{0}$ ditolak. Dengan demikian bahwa ada pengaruh yang signifikan antara lingkungan kerja dan motivasi berprestasi secara bersama terhadap 
kinerja guru Madrasah Ibtidaiyah di Kecamatan Aikmel.

Tabel 12 Persamaan Regresi antar Variabel

Coefficients $^{a}$

\begin{tabular}{|c|c|c|c|c|c|}
\hline \multirow[b]{2}{*}{ Model } & \multicolumn{2}{|c|}{$\begin{array}{l}\text { Unstandardize } \\
\text { d Coefficients }\end{array}$} & \multirow{2}{*}{$\begin{array}{c}\begin{array}{c}\text { Standar } \\
\text { dized } \\
\text { Coeffici } \\
\text { ents }\end{array} \\
\text { Beta }\end{array}$} & \multirow[b]{2}{*}{$\mathrm{T}$} & \multirow[b]{2}{*}{ Sig. } \\
\hline & B & $\begin{array}{l}\text { Std. } \\
\text { Error }\end{array}$ & & & \\
\hline $1 \quad$ (Constant) & 30.421 & 8.643 & & 3.520 & .001 \\
\hline $\begin{array}{l}\text { Lingkungan } \\
\text { Kerja }\end{array}$ & .289 & .100 & .320 & 2.881 & .006 \\
\hline $\begin{array}{l}\text { Motivasi } \\
\text { Berprestasi }\end{array}$ & .412 & .109 & .420 & 3.783 & .000 \\
\hline
\end{tabular}

a. Dependent Variable:

Kinerja Guru

Diketahui nilai constant pada tabel variabel kinerja guru pada tabel 12. yakni terdapat nilai positif yang menunjukkan adanya pengaruh dari variabel $X_{1}$ dan variabel $X_{2}$, di mana nilai constan yang diperoleh yakni 30,421 pada aras signifikan $0,05>0,001$. Dengan kata lain, adanya persamaan regresi atau pengaruh koefisien yang positif dari ketiga variabel tersebut. Hal ini diketahui berdasarkan koefisien regresi pada variabel $X_{1}$ mengalami peningkatan sebesar 0,289 atau 28,9\%. Hal ini menunjukkan koefisien nilai positif antara lingkungan kerja $\left(\mathrm{X}_{1}\right)$ dengan kinerja guru (Y). Selanjutnya pada variabel $\mathrm{X}_{2}$ juga mengalami peningkatan sebesar 0,412 atau $41,2 \%$ antara motivasi berprestasi $\left(\mathrm{X}_{2}\right)$ dengan kinerja guru $(\mathrm{Y})$. Berdasarkan hasil tersebut, dapat dikatakan bahwa koefesien kedua variabel antara variabel $\mathrm{X}_{1}$ dan $\mathrm{X}_{2}$ memiliki peran yang dapat meningkatkan kerja guru (Y) di Madrasah Ibtidaiyah Kecamatan Aikmel. Lebih lanjut, untuk mengetahui pengaruh lingkungan kerja dan motivasi berprestasi secara bersamasama terhadap kinerja guru melalui nilai $\mathrm{R}$ sebagai berikut.

Tabel 13. Model Summary Lingkungan Kerja dan Motivasi Berprestasi terhadap Kinerja Guru

\begin{tabular}{|l|r|r|r|r|}
\multicolumn{5}{|c}{ Model Summary $^{\mathrm{b}}$} \\
\hline Model & $\mathrm{R}$ & $\mathrm{R}$ Square & $\begin{array}{c}\text { Adjusted R } \\
\text { Square }\end{array}$ & $\begin{array}{c}\text { Std. Error of } \\
\text { the Estimate }\end{array}$ \\
\hline 1 & $.599^{\mathrm{a}}$ & .359 & .336 & 5.339 \\
\hline
\end{tabular}

a. Predictors: (Constant), Motivasi Berprestasi,

Lingkungan Kerja

b. Dependent Variable: Kinerja

Guru 
Berdasarkan pada tabel 4.19 diketahui nilai Pearson Correlation $(\mathrm{R})=$ 0,599 yang berarti tingkat hubungan atau pengaruh variabel lingkungan kerja dan motivasi berprestasi terhadap kinerja guru berapada pada kategori "cukup" dengan determinasi kontribusi pengaruh lingkungan kerja dan motivasi berprestasi terhadap kinerja guru Madrasah Ibtidaiyah di Kecamatan Aikmel berada pada kisaran R Square 0,359 atau $35,9 \%$.

\section{Pembahasan Hasil Penelitian}

Kinerja pada dasarnya merupakan kerja dari seorang individu untuk mencapai hasi-hasil tertentu. Dalam hal ini, kinerja seorang atau individu seorang guru dalam menentukan terhadap kualitas pendidikan karena kinerja yang baik akan mendorong (mempercepat) tercapainya tujuan pendidikan Nasional. Kinerja guru khususnya di Madrasah Ibtidaiyah di Kecamatan Aikmel dapat ditingkatkan apabila komponenkomponen yang mempengaruhinya dapat diidentifikasi dan dioptimalkan untuk pencapaian tujuan pembelajaran. Untuk mencapai kinerja yang diharapkan dalam meningkat kualitas pembelajaran tentunya terdapat beberapa faktor sebagai pendongkrak dalam meningkatkan kualitas kinerja terutama pada seorang guru. Komponen atau faktor yang dirasa sbagai bagian untuk meningkatkan kinerja guru yakni faktor lingkungan kerja dan dan motivasi berprestasi.

Sehubungan dengan hal tersebut, berdasarkan penyebaran kuesioner lingkungan kerja dan motivasi berprestasi terhadap kinerj guru pada responden atau guru Madrasah Ibtidaiyah di Kecamatan Aikmel. Diperoleh hasil penelitian yang diuji dengan menggunakan statistik deskriptif, normalitas, homogenitas, multicollinearity, heteroskedastisitas, parsial (Uji-t), dan persamaan regresi linieritas ganda.

Pada variabel lingkungan kerja rerata yang diperoleh dari 60 responden sebesar 70.216 dengan nilai tertinggi 96 dan nilai terendah 52, sedangkan pada variabel motivasi berprestasi diperoleh rerata dari 60 responden 68.716 dengan nilai tertinggi 83 dan nilai terendah 47 . Berdasarkan rerata yang diperoleh pada kedua variabel bebas tersebut, variabel lingkungan kerja lebih mendominasi daripada variabel motivasi berprestasi disebabkan nilai rerata variabel lingkungan kerja 70,216 lebih besar daripada nilai rerata variabel motivasi berprestasi yakni 68,716. Lebih lanjut, untuk variabel kinerja guru diperoleh rarata dari 60 responden sebesar 79.016 dengan nilai tertinggi 97 dan nilai terendah 65. Rerata yang diperoleh variabel kinerja guru 79,016 lebih besar dari kedua variabel bebas, hal ini membuktikan bahwa adanya peningkatan kinerja guru yang disebabkan oleh kedua variabel bebas tersebut.

Untuk membuktikan data tersebut, telah dilakukan uji normalitas data, di mana diperoleh hasil pada variabel kinerja guru sebesar 0.078 , variabel motivasi berprestasi 0,709 , dan variabel lingkungan kerja 0,526 pada aras signifikan $5 \%$ atau 0,05 , dapat dikatakan tiap-tiap variabel tersebut berdistribusi normal. Selain menguji normalitas tiaptiap variabel, secara keseluruhan Unstandardized Residual diperoleh nilai 0,583, ini menunjukkan secara keseluruhan data tersebut berdistribusi normal pada aras signifikan 5\% $(0,583>0,05)$. Begitu juga pada uji homogenitas, yakni menguji keseragaman data ketiga variabel tersebut dengan membandingkan varian terbesar dengan varian terkecil sehingga diperoleh $\mathrm{f}_{\mathrm{h}} \quad 1.227$ pada aras signifikan $0.05 \%$ dengan derajat bebas pembilang $(\mathrm{db}) \quad \mathrm{n}-1=60-1=59$ dan 
penyebut (db) $\mathrm{n}-1=60-1=59$ sehingga diperoleh $\quad \mathrm{f}_{\mathrm{t}_{\mathrm{i}}} \quad 1,52 \quad\left(\mathrm{f}_{\mathrm{h}} \quad 1.227<\right.$ $\mathrm{f}_{\mathrm{t}_{i}} \quad$ 1.52) ini mebuktikan ketiga variabel tersebut homogen. Selain dari uji normalitas dan homogenitas, untuk membuktikan kesahihan data tersebut, dilakukan juga uji multicollinearits nilai VIF sebesar 1.097 dan nilai tolerance sebesar 0,912 pada aras signifikan 5\% atau 0,05 , serta uji heteroskedastisitas nilai Unstandardized Residual Absolut yakni 0,100 pada aras signifikan 0,05 $(0,100>0,05)$. Berdasarkan hasil analisis data tersebut dapat dinyatakan ketiga variabel tersebut sudah layak.

Untuk memenuhi hipotesis bahwa ada pengaruh lingkungan kerja dan motivasi berprestasi terhadap kinerja guru Madrasah Ibtidaiya di Kecamatan Aikmel. Hipotesis pertama bahwa $\mathrm{f}_{\mathrm{h}}$ $=14.318$ dengan aras signifikan atau probalitas $0.000<0.05$, maka model regresi dapat dipakai untuk memprediksi variabel kinerja guru. Untuk mengetahui persamaan regresi variabel lingkungan kerja terhadap kinerja guru yakni diperoleh nilai constant sebesar 50,815 dan nilai variabel lingkungan kerja sebesar 0,402, artinya ada peningkatan yang positif antara variabel lingkungan kerja terhadap kinerja guru. Lebih lanjut, selain menguji persamaan regresi sederhana pada output di atas, diketahui nilai $t_{h}=3,784$ dengan nilai signifikansi $0,000<0,05$, maka $\mathrm{H}_{0}$ ditolah dan $\mathrm{H}_{\mathrm{a}}$ diterima. Dengan demikian, dapat dikatakan bahwa ada pengaruh yang signifikan variabel lingkungan kerja terhadap kinerja guru. Adapun besar hubungan atau pengaruh diperoleh nilai Koefisiensi (R) 0,445 dengan determinasi $\mathrm{R}^{2} \quad 0,198$ atau $19,8 \%$. Dengan demikian hipotesis pertama terpenuhi yakni ada pengaruh lingkungan kerja terhadap kinerja guru Madrasah Ibtidaiyah di Kecamatan Aikmel.
Selanjutnya, Hipotesis kedua bahwa $\mathrm{f}_{\mathrm{h}} \quad=20,977$ dengan aras signifikan atau probalitas $0.000<0.05$, maka model regresi dapat dipakai untuk memprediksi variabel kinerja guru. Untuk mengetahui persamaan regresi variabel motivasi berprestasi terhadap kinerja guru yakni diperoleh nilai constant sebesar 44,288 dan nilai variabel motivasi berprestasi sebesar 0,505, artinya ada peningkatan yang positif antara variabel motivasi berprestasi terhadap kinerja guru. Lebih lanjut, selain menguji persamaan regresi sederhana pada output di atas, diketahui nilai $t_{h}=4,580$ dengan nilai signifikansi $0,000<0,05$, maka $\mathrm{H}_{0}$ ditolah dan $\mathrm{H}_{\mathrm{a}}$ diterima. Dengan demikian, dapat dikatakan bahwa ada pengaruh yang signifikan variabel motivasi berprestasi terhadap kinerja guru. Adapun besar hubungan atau pengaruh diperoleh nilai Koefisiensi (R) 0,515 dengan determinasi $\mathrm{R}^{2} 0.266$ atau $26,6 \%$

Hipotesis ketiga yang diajukan yakni ada atau tidak pengaruh lingkungan kerja dan motivasi berprestasi secara bersamasama terhadap kinerja guru Madrasah Ibtidaiyah di Kecamatan Aikmel. Hasil hipotesis ketiga yang diajukan pada aras signifikan $0,5 \%$ diperoleh $\mathrm{f}_{\mathrm{h}} \quad 15,959$ $>\mathrm{f}_{\mathrm{t}_{\mathrm{i}}} \quad 3,16$, maka $H_{a}$ diterima dan $H_{0}$ ditolak. Selain uji F, dilihat persamaan regresi yang diperoleh yakni nilai constan 30,421 pada aras signifikan 0,05 $>0,001$. Koefisien regresi pada variabel $X_{1}$ mengalami peningkatan sebesar 0,289 atau $28,9 \%$ dan variabel $X_{2}$ juga mengalami peningkatan sebesar 0,412 atau $41,2 \%$. Adapun untuk mengetahui besar hubungan atau pengaruh lingkungan kerja dan motivasi secara bersama-sama terhadap kinerja guru, diperoleh Pearson Correlation (R) = 0,599 yang berarti tingkat hubungan atau pengaruh variabel lingkungan kerja dan motivasi berprestasi terhadap kinerja guru berapada pada kategori "cukup" 
dengan determinasi kontribusi berada pada kisaran R Square 0,359 atau 35,9\%.

Sesuai dengan cakupan hasil tersebut, dapat dikatakan bahwa untuk meningkatkan kinerja guru dibutuhkan faktor-faktor pendukung dalam meningkatakan kualitas guru dalam mengembangkan pembelajaran di sekolah terutama pada Madarasah Ibtidaiyah di Kecamatan Aikmel. Upaya

\section{SIMPULAN DAN SARAN}

\section{Simpulan}

Berdasarkan hasil analisis dan pembahasan pada bab IV, dapat disimpulkan sebagai berikut.

1. Ada pengaruh yang signifikan lingkungan kerja terhadap kinerja guru Madrasah Ibtidaiyah di Kecamatan Aikmel yakni $t_{h}=$ 3,784 dengan nilai signifikansi $0,000<0,05$, maka $\mathrm{H}_{0}$ ditolah dan $\mathrm{H}_{\mathrm{a}}$ diterima. Besar hubungan atau pengaruh interpretasi (R) 0,445 dengan determinasi $\mathrm{R}^{2} \quad 0,198$ atau $19,8 \%$.

2. Ada pengaruh yang signifikan motivasi berprestasi terhadap kinerja guru Madrasah Ibtidaiyah di Kecamatan Aikmel yakni $t_{h}=$ 4,580 dengan nilai signifikansi $0,000<0,05$, maka $\mathrm{H}_{0}$ ditolah dan $\mathrm{H}_{\mathrm{a}}$ diterima. Besar hubungan atau pengaruh interpretasi (R) 0,515 dengan determinasi $\mathrm{R}^{2} \quad 0,266$ atau $26,6 \%$.

3. Ada pengaruh yang signifikan lingkungan kerja dan motivasi berprestasi secara bersama-sama terhadap kinerja guru Madrasah Ibtidaiyah di Kecamatan Aikmel yakni $\mathrm{f}_{\mathrm{h}} \quad 15,959>\mathrm{f}_{\mathrm{t}} \quad 3,16$, maka $H_{a}$ diterima dan $H_{0}$ ditolak. Besar hubungan atau pengaruh berada pada kategori "cukup" mengacu pada interpretasi $(\mathrm{R}) \quad 0,599$ dengan determinasi $\mathrm{R}^{2}$ 0,359 atau 35,9\%. yang perlu dilakukan yakni memanfaatkan sebaik mungkin lingkungan kerja dan motivasi prestasi yang dimiliki sebagai upaya dalam mengefisienkan kinerja dalam melaksanakan proses pembelajaran. Kinerja baik seorang guru sangat dibutuhkan oleh pihak sekolah. Semakin baik kinerja guru maka semakin baik pula hasil yang diperoleh.

\section{Saran}

Berdasarkan pembahasan, kesimpulan, dan implikasi di atas maka dapat diberikan beberapa saran sebagai berikut :

\section{Saran bagi Guru}

Sesuai dengan pembahasan memberikan informasi bahwa peran lingkungan kerja dan motivasi berprestasi Madrasah Ibtidaiyah di Kecamatan Aikmel mempunyai pengaruh yang cukup terhadap Kinerja Guru yakni sebesar 35,9\%. Ini membuktikan semakin baik lingkungan kerja dan motivasi berprestasi guru semakin baik pula kinerja guru. Dari pernyataan tersebut Guru hendaknya selalu meningkatkan kedisplinan dan rasa tanggung jawab. Seorang guru hendaknya memanfaatkan lingkungan kerja dengan baik, dapat mudah berkomunikasi dengan teman sejawat dan mengikuti organisasi kemasyarakatan guna menunjang peningkatan kinerja guru. Demikian juga, motivasi berprestasi guru, semakin tinggi motivasi breprestasi guru untuk melaksanakan kewajibannya maka semakin tinggi pula kinerja guru pada sekolah tersebut.

2. Saran untuk penelitian selanjutnya Penelitian ini memberikan informasi bahwa faktor Lingkungan Kerja dan 
Motivasi Berprestasi Guru mempunyai pengaruh terhadap Kinerja Guru sebesar $35,9 \%$. Untuk itu perlu adanya penelitian lebih lanjut tentang faktor-faktor yang mempengaruhi Kinerja Guru, karena Kinerja Guru tidak hanya dipengaruhi

\section{DAFTAR PUSTAKA}

Anonim. 2003. Hubungan Gaya Kepimpinan dan Motivasi Di Kalangan Guru-Guru Sekolah Menengah Zon A Di Bahagian Kuching, Sarawak, diakses dari ; http://www.Webcasmy.com, diakses tanggal 10 Juni 2003.

Arikunto, S. 2005. Manajemen

Penelitian. Jakarta: Rineka Cipta.

Arikunto. S. 2000. Manajemen

Penelitian. Jakarta: PT Rineka Cipta.

Arsyad, A.2000. Media Pengajaran. Rajawali Pers. Jakarta.

Darmawan, I.M.Y., 2011. Pengaruh Kompensasi dan Lingkungan Kerja Non Fisik terhadap Disiplin dan Kinerja Karyawan Hotel Nikki Denpasar. Tesis. Universitas Udayana. Tidak Diterbitkan.

Djamarah, dan Aswan Zain. 2002.

Strategi Belajar Mengajar. Rineka

Cipta Jakarta.

Djamarah, S.J. 2000. Prestasi Belajar dan Kompetensi Guru. Usaha Nasional: Surabaya.

Fatah, N. 2004. Konsep Manajemen Berbasis Sekolah (MBS) dan Dewan Sekolah. Pustaka Bani Quraisy. Bandung.

Fattah, N. 2000. Landasan Manajemen Pendidikan. PT Remaja Rosdakarya. Bandung

Gibson, James L., John M. Ivancevich dan James H. Donelly, Jr. 1991. Organizations: Behaviour, Structure, Processes. oleh lingkungan kerja dan motivasi berprestasi tetapi masih banyak faktor lain yang turut mempengaruhinya, seperti kecerdasan emosional guru, kepemimpinan kepala sekolah, sertifikasi guru, dan lain-lain.

Homewood, III: Richard D. Irwin.

Hamalik, O. 2002. Psikologi Belajar Mengajar. Sinar Baru. Bandung. Hasibuan, S.P. Melayu. 1996. Manajemen Dasar Pengertian dan Masalah. Jakarta: Gunung Agung.

Hasibuan, S.P. Melayu. 2001. Manajemen Sumber Daya Manusia. Jakarta: Bumi Aksara.

Hersey, Paul, Keneth H. Blanchard, Dewey E. Johnson. 1996. Management of Organizational Behaviour. New Jersey: Prentice Hall.

Ibrahim dan Syaodih. 1996. Perencanaan Pengajaran. Rineka Cipta. Jakarta.

Ikhwari, 2014. Pengaruh Kepemimpinan Kepala Sekolah,Iklim Kerjasama, Komunikasi Interpersonal dan Disiplin Kerja terhadap Kinerja Guru SMPN Se-Kabupaten Pasaman Barat. Tesis. Pascasarjana. Universitas Negeri Padang. Tidak Diterbitkan.

Iskandar, Ambarita, dan Sowiyah (2014). Pengaruh Kecerdasan Emosional dan Motivasi Berprestasi terhadap Kinerja Guru Yayasan Pendidikan Panjang Lampung (YPPL) di Bandar Lampung Tahun 2014. Jurnal online FKIP Unila. (https://www.google.co.id/?gws rd. diakses Tanggal $15 \mathrm{Mei}$ 2016).

Lembaga Administrasi Negara. 2007. Manajemen Perkantoran: Diklat 
Teknis Administrasi Umum. LAN Jakarta.

Mangkuprawira, Sjafri. 2010. Bisnis, Manajemen, dan Sumber Daya Manusia. IPB Press, Bogor.

Mathis, Robert L, and John H. Jackson. 2000. Human Resource Management, New York SouthWestern College Publishing.

Moekijat. $1989 . \quad$ Manajemen Kepegawaian.

Alumni. Bandung.

Ningsih, Y. Hubungan Iklim Sekolah, Beban Tugas, Motivasi Berprestasi dan Kepuasan Kerja Guru dengan Kinerja Guru Sekolah Dasar Negeri di Kota Mojokerto. Desertasi. Tidak dipublikasi.

Nitisemito, A. S. 2002. Manajemen Personalia. Edisi Revisi. Ghalia, Jakarta.

Nurgiantoro. 1992. Kinerja Pegawai. Gramedia. Jakarta

Pareek, Udai. 1989. Perilaku Organisasi. Jakarta: Karya Unipress.

Permansari, R. 2013. Pengaruh Motivasi dan lingkungan Kerja terhadap Kinerja PT. Anugrah Raharjo Semarang.

Putra, C.A.A., Yudana, M., dan Natajaya, N. 2013. Hubungan Motivasi Berprestasi, Prilaku Kepemimpinan Kepala Sekolah dan Etos Kerja dengan Kinerja Guru di SMAN 1 Kubutambahan. e-Journal Program Pascasarjana Universitas Pendidikan Ganesha Program Studi Administrasi Pendidikan (Volume 4 Tahun 2013).

Rabideau, S.T. 2005. Effect of Achievement Motivation on Behavior. http://www.personalityresearch. org/papers/rabideau.html. Di akses, 26 mei 2016.
Rahmawati E. 2014, Pengaruh Lingkungan Sekolah terhadap Motivasi Belajar Siswa Kelas VIII3 SMP Muhammadiyah 22 Pamulang, Jurnal Fakultas lmu Tarhiyah dan Keguruan Universitas Islam Negeri Syarif Hidayatullah Jakarta.

Ralahulu, E.M. 2014. Pengaruh Motivasi dan Lingkungan Kerja Perawat terhadap Kinerja Perawat di Rumah Sakit PKU Muhammadiyah Yogyakarta. Tesis. Program Pascasarjana. UM Yogyakarya. Tidak dipublikasi

Riyanto, Y. 2007. Metodologi Penelitian Pendidikan. Surabaya: SIC.

Robbins, P.S. 2015. Perilaku Organisasi, Terjemahan, Edisi 16 Bahasa Indonesia. Salemba empat, Jakarta.

Roestiyah. 2001. Strategi Belajar Menga jar. Rineka Cipta . Jakarta.

Rustini, N.K.A., $2015 . \quad$ Pengaruh Kompensasi dan Lingkungan Kerja pada Komitmen Organisasi dan Implikasinya Pada Kinerja Pengelola Anggaran. Tesis. Program Pascasarjana. Universitas Udayana. Denpasar.

Sardiman, AM. 2004. Insteraksi dan Motivasi Belajar mengajar, Pedoman Bagi Calon Guru. Rajawali Press. Jakarta:

Sedarmayanti. 2001. Sumber Daya Manusia dan Produktivitas Kerja. Mandar Maju, Bandung.

Siagian, S.P., 2008. Manajemen Sumber Daya Manusia. Bumi Aksara. Jakarta.

Suastha, Nyoman. T., 2006. Evaluasi Kinerja dan Sistem Manajemen SDM. UIEU, Jakarta.

Sudarmanto. 2014. Kinerja dan Pengembangan Kompetensi SDM. Yogyakarta: Puataka pelajar 
Sugiyono. 2007. Metode Penelitian Administrasi. Bandung: Alfabeta.

Sugiyono. 2011. Pengaruh Pendidikan Pelatihan, Motivasi Kerja, dan Lingkungan Kerja terhadap Kinerja Guru. Jurnal Manajemen Sumberdaya Manusia Vol. 5 No. 1 Juni 2011: 1 - 10 .

Suharsaputra. 2013. Administrasi Pendidikan. Bandung : PT Refika Aditama.

Supardi, 2013. Kinerja Guru. Rajagrafindo Persada. Jakarta.

Suparno. 2007. Pengaruh Motivasi Kerja dan Kepemimpinan Situasional Kepala Sekolah terhadap Kinerja Guru SMP Negeri di Kecamatan Pemalang Kabupaten Pemalang.

Suryadarma, Daniel. 2011. The Quality of Education in Indonesia:

Weighed, Measured, and Found Wanting, Australian National University, Presented at Forum Kajian Pembangunan Seminar Series, SMERU Research Institute, Jakarta, 18 May 2011.

Tartib (2015) dalam penelitiannya yang berjudul Pengaruh Lingkungan Kerja dan Kepuasan Kerja terhadap Kinerja Guru pada SMP Pasundan 6 Bandung dan SMK Pasundan 3 Bandung.(www.google.co.id/?g ws rd diakses tanggal 15 Mei 2016).
Wahjosumidjo. 1984. Kepemimpinan dan Motivasi. Jakarta: Ghalia Indonesia.

Wahjosumidjo. 2001. Kepala sekolah : Tinjauan teoritis dan permasalahannya. Jakarta : Rajawali Perss.

Waworuntu, J. 2011. Hubungan Antara Motivasi Berprestasi dan Kinerja Profesional Guru Teknologi SMK Negeri 2 Manado. Jurnal Elektromatika. Prodi Pendidikan Teknik Elektro Unima, Vol. 1(1), Maret 2011.

Wibowo. 2010. Manajemen Kinerja Edisi Ketiga. Rajawali Pers, Jakarta.

William B. Werther Jr, and Keith Davis 2003. Human Resources and Personal Management. McGraw Hill, inc. New York.

Winardi. 1971. Organisasi Perkantoran Modern. Bandung: Alumni.

Wiyono, G. 2011. Merancang Penelitian Bisnis dengan Alat Analisis SPSS 12 \& SmartPLS 2.0. UPP STIM YKPN. Yogyakarta.

Wursanto, Ignasius. 2009. Dasar-Dasar Ilmu Organisasi.Edisi dua. Andi Offset. Yogyakarta.

Yamin, S. dan Kurniawan, H., 2014. SPSS Complete: Teknik Analisis Statistik Terlengkap dengan Sofware SPSS. Salemba Ifotek. Jakarta. 